УДК 655.3.022.1

๑ В. Ф. Морфлюк, д.Т.н., професор, Є. В. Сироватка, магістр, НТУУ «КПІ», Київ, Україна

\title{
ЗАСОБИ ЦИФРОВОГО ВИЗНАЧЕННЯ ТА СТАБІЛІЗАЦІЇ ТЕМПЕРАТУРНОГО РЕЖИМУ СУШИЛЬНОГО АПАРАТА ДРУКАРСЬКИХ МАШИН
}

У статті представлена організація цифрових програмноапаратних засобів визначення та стабілізації температурного режиму сушильного апарату друкарських машин, які забезпечують об'єктивність інтегральної оцінки вимірювань в реальному масштабі часу на основі проблемної орієнтації.

Ключові слова: температура сушильного апарату друкарських машин; програмно-апаратні засоби 3 проблемною орієнтацією; інтегральне статистичне вимірювання; стабілізація температурного режиму.

\section{Постановка проблеми}

Якість друкованої продукції в значній мірі залежить від процесу сушіння відбитків після нанесення на них шарів фарби та лаку.

Процес сушіння відбитків потребує підтримки оптимальної робочої температури сушильного апарату друкарських машин упродовж усього технологічного процесу друку, що вимагає подальшого вдосконалення методів та засобів оперативного контролю та регулювання температурного режиму. Визначено, що робоча температура процесу сушіння для ряду процесів не повинна перевищувати 54$55^{\circ}$ С. При неконтрольованому збільшенні температури сушіння загальний вигляд зображення на відбитку може спотворюватися, тобто відбувається процес розтріскування фарбового та лакового шару або зморщуван- ня відбитку. Ефективність застосування процесів оперативного контролю та регулювання температурного режиму залежить від ефективності застосування сучасних програмно-апаратних засобів для вимірювання, аналізу та регулювання температури сушіння. У зв'язку з цим виникає задача автоматизації процесу стабілізації температурного режиму сушіння, що обумовлює проведення досліджень та удосконалення системи об'єктивного визначення та регулювання температури сушіння у друкарських машинах на основі сучасних цифрових програмно-апаратних засобів у реальному масштабі часу [1-3].

\section{Аналіз попередніх} досліджень

Аналіз технічних засобів для визначення та стабілізації температурного режиму су- 


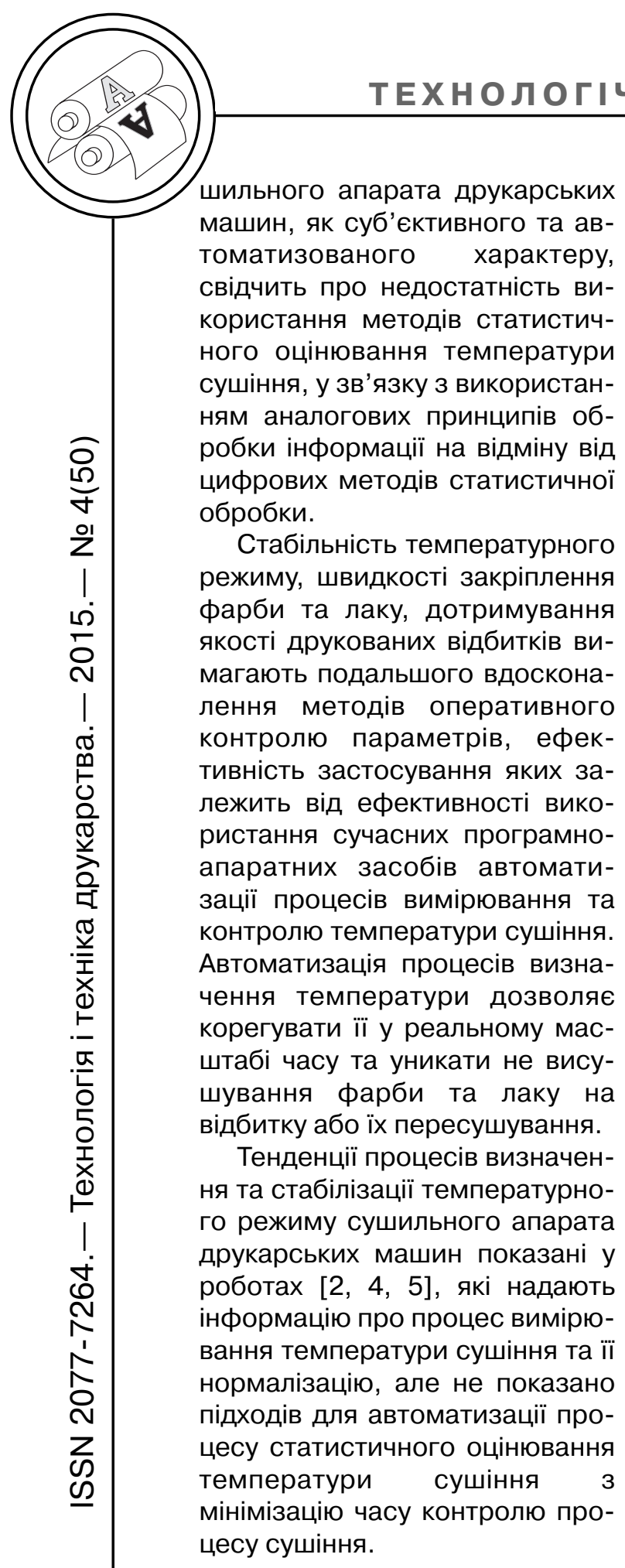

Мета роботи

Метою дослідження $€$ аналіз та розробка ефективної системи об'єктивного цифрового визначення температурного режиму сушильного апарату друкарських машин для його стабілізації у реальному масштабі часу, з використанням сучасних, швидкодіючих програмно-апаратних засобів цифрової обробки інформації та програмного керування.

\section{Результати проведених досліджень}

Для забезпечення якості друкованої продукції необхідна

оптимізація технологічного процесу визначення та стабілізації температурного режиму сушильного апарату друкарських машин. При неконтрольованому збільшенні температури сушіння загальний вигляд зображення на відбитку може спотворюватися, тобто відбувається процес небажаної зміни відбитка (зморщування відбитку; поява ефекту апельсинової кірки, а також розтріскування лакового шару).

Однією з умов отримання якісного відбитка є забезпечення оптимальної температури сушіння друкарського відбитка, яка залежить від збереження стабільності температури сушіння за рахунок застосування програмно-апаратних засобів об'єктивного контролю та регулювання [2, 3].

В ході дослідження розглядається комбінований сушильний апарат з інфрачервоним опромінюванням (14) 3 ультрафіолетовим сегментом опромінювання (УФ) та час його ефективної дії на друкарські відбитки. Згідно зазначеного у роботі досліджувалась зміна температури ( $T_{S}$ ) сушильного 
апарату друкарських машин залежно від часу впливу температури сушіння $\left(t_{s}\right)$ у процесі друку на основі інтегральної оцінки статистичних вимірювань температури сушіння для визначення функціональної залежності $\mathrm{T}_{\mathrm{s}}=\mathrm{f}\left(\mathrm{t}_{\mathrm{s}}\right)$, з метою мінімізації процесу контролю температури сушіння при удосконаленні друкарських машин.

Експериментальне дослідження проводились у виробничих умовах на офсетній друкарській машині з визначеними температурними режимами сушильних апаратів (14 $50^{\circ} \mathrm{C}-$ УФ $40 \%$, $1450 \circ \mathrm{C}$ - УФ $50 \%$, $1450^{\circ} \mathrm{C}-$ УФ 60 \%). Визначення температури виконувалось на основі статистичних вимірювань (4-и виміри) по п'яти датчиках Д1-Д5 на відбитках рис. 1, з інтервалом у 5 хвилин до перевищення максимально допустимої температури та розрахунку інтегральної оцінки температури (середнє арифметичне значення на основі статистичних вимірювань).

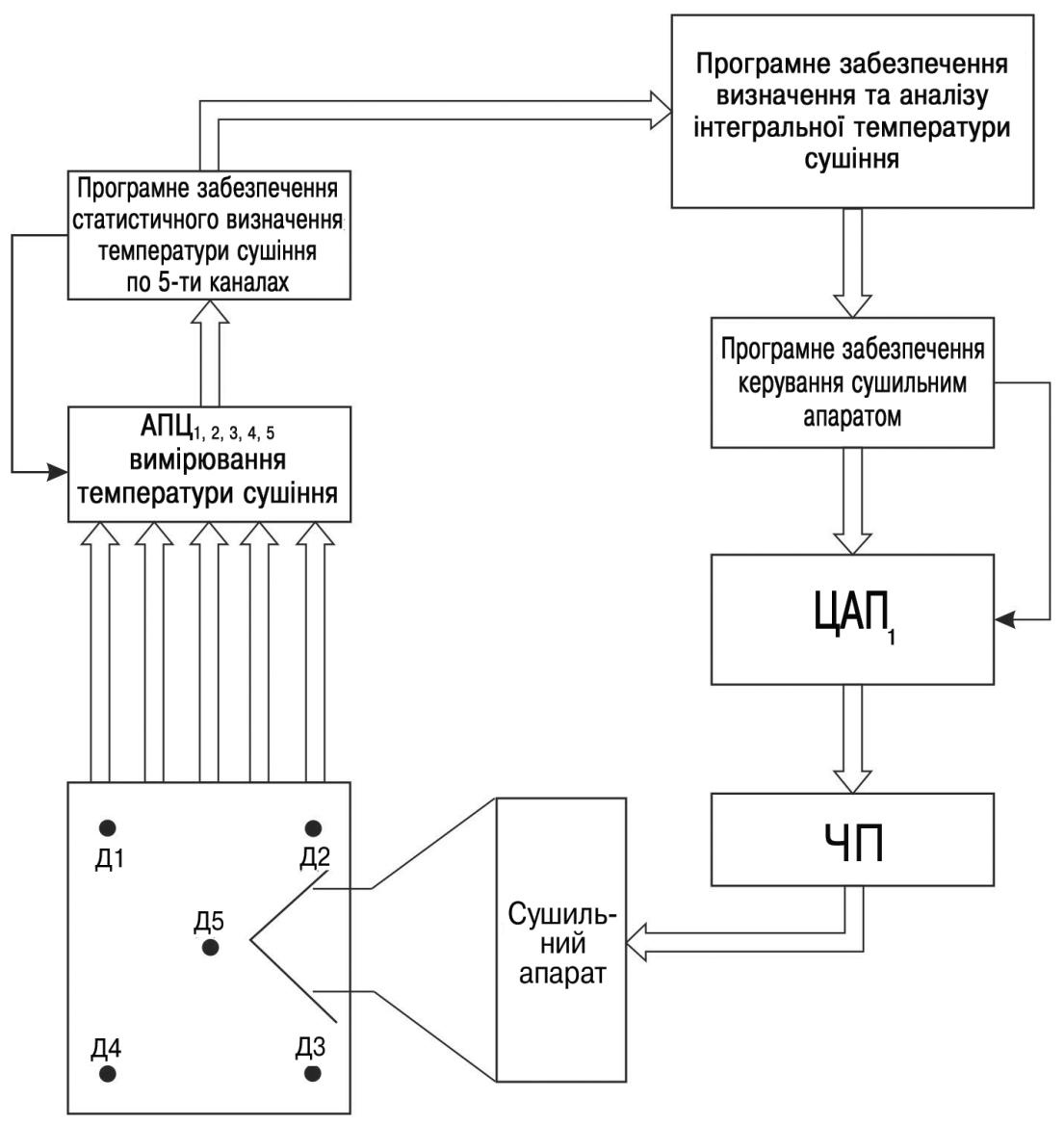

Рис. 1. Структурна схема системи цифрової стабілізації температурного режиму сушильного апарату 
В таблицях 1-3 представлено результати статистичного вимірювання та обробки значення температури сушіння залежно від часу впливу температури сушіння для трьох режимів, а на рис. 2-4 графіки залежності інтегральної температури сушіння від часу сушіння $T_{S}=f\left(t_{s}\right)$ та ї визначена аналітична інтерпретація:

$$
\begin{gathered}
\mathrm{T}_{\mathrm{S}}=\frac{\sum_{\mathrm{i}=1}^{\mathrm{n}} \mathrm{t}_{\text {म11 }}+\sum_{\mathrm{i}=1}^{\mathrm{n}} \mathrm{t}_{\text {Д2i }}}{5 \times \mathrm{n}}+ \\
+\frac{\sum_{\mathrm{i}=1}^{\mathrm{n}} \mathrm{t}_{\text {Д3i }}+\sum_{\mathrm{i}=1}^{\mathrm{n}} \mathrm{t}_{\text {д4i }}+\sum_{\mathrm{i}=1}^{\mathrm{n}} \mathrm{t}_{\text {Д5i }}}{5 \times \mathrm{n}}
\end{gathered}
$$

де $t_{\text {д1i }}, t_{2 i}, t_{д 3 і}, t_{д 4 i}, t_{д 5 i}-c т а-$ тистичні значення температури відповідного датчика; $\mathrm{n}$ кількість статистичних вимірів; і — номер виміру (від 1 до n) ; 5 кількість датчиків.

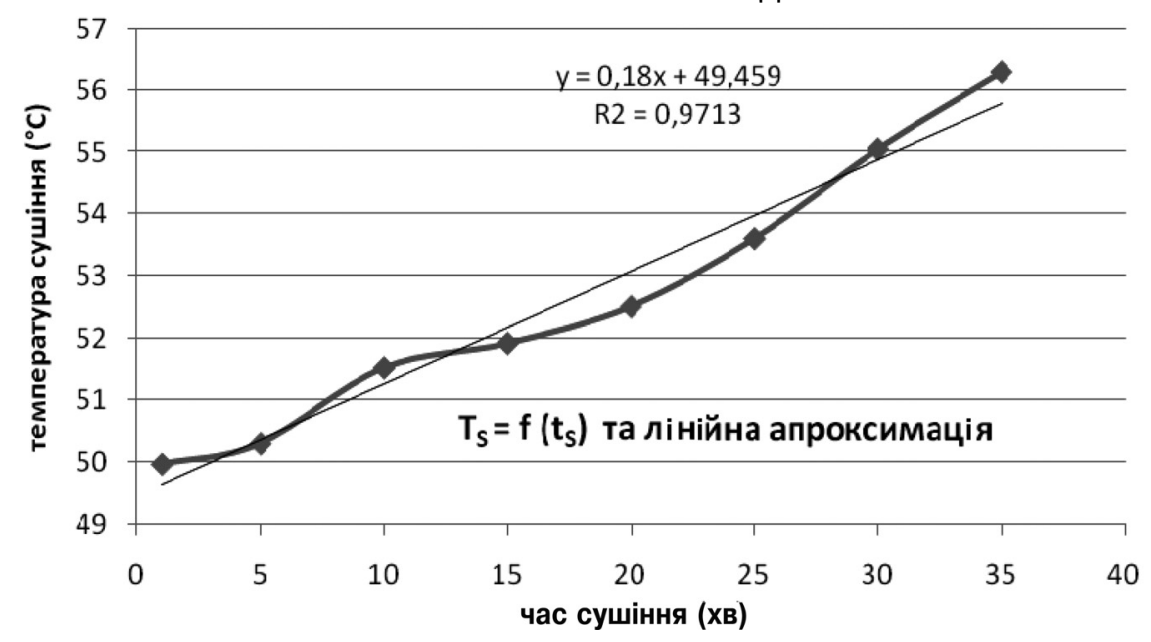

Рис. 2. Графік зміни інтегральної температури $\left(T_{S}\right)$ сушильного апарату від часу впливу $\left(t_{S}\right)$ з першим режимом сушіння

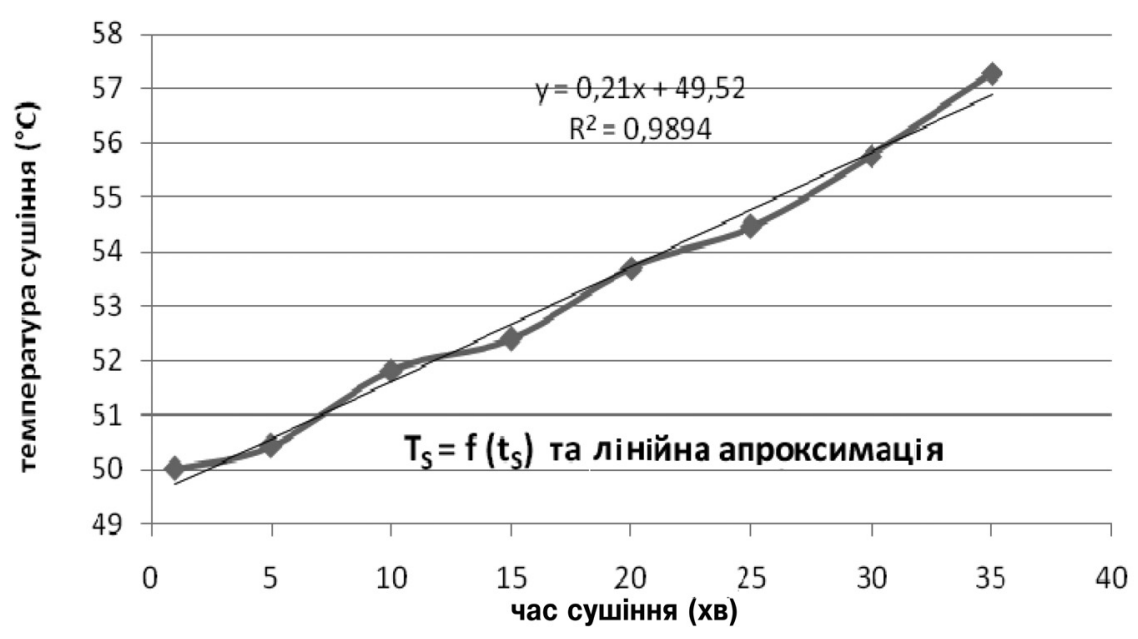

Рис. 3. Графік зміни інтегральної температури $\left(T_{S}\right)$ сушильного апарату від часу впливу $\left(\mathrm{t}_{\mathrm{S}}\right)$ з другим режимом сушіння 
Таблиця 1

Результати вимірювання температури з першим режимом сушіння

\begin{tabular}{|c|c|c|c|c|c|c|c|c|}
\hline $\begin{array}{c}\text { Хар- } \\
\text { ки }\end{array}$ & $\begin{array}{l}\text { Час, } \\
\text { хв. }\end{array}$ & $\begin{array}{c}\text { ДатчикД, } \\
{ }^{\circ} \mathrm{C}\end{array}$ & $\begin{array}{c}\text { ДатчикД }, \\
{ }^{\circ} \mathrm{C}\end{array}$ & $\begin{array}{c}\text { ДатчикД }, \\
{ }^{\circ} \mathrm{C}\end{array}$ & $\begin{array}{c}\text { ДатчикД }, \\
{ }^{\circ} \mathrm{C}\end{array}$ & $\begin{array}{c}\text { ДатчикД } \\
{ }^{\circ} \mathrm{C}\end{array}$ & $\begin{array}{c}\text { Інтегральна } \\
\text { t, }{ }^{\circ} \mathrm{C}\end{array}$ & $\begin{array}{c}\text { Рекомендації } \\
\text { до стабілізації } \\
\text { температурного } \\
\text { режиму }\end{array}$ \\
\hline \multirow{40}{*}{ 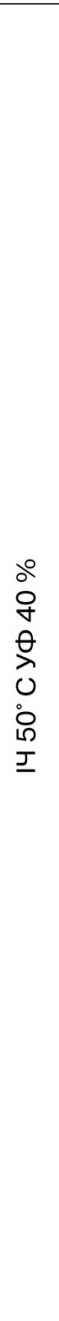 } & \multirow[t]{4}{*}{1} & 49,01 & 49,41 & 50,26 & 49,99 & 50,01 & & \multirow{5}{*}{$\begin{array}{c}\text { Не потрібно } \\
\text { контролювати }\end{array}$} \\
\hline & & 49,54 & 50,00 & 50,00 & 50,01 & 49,99 & & \\
\hline & & 50,01 & 51,07 & 49,98 & 50,00 & 50,04 & & \\
\hline & & 50,09 & 50,01 & 50,10 & 50,13 & 50,00 & & \\
\hline & $t_{c p}$ & 50,007 & 49,6625 & 50,1225 & 50,085 & 50,0325 & 49,98 & \\
\hline & \multirow[t]{4}{*}{5} & 50,28 & 50,25 & 50,25 & 50,29 & 50,31 & & \multirow{5}{*}{$\begin{array}{c}\text { Не потрібно } \\
\text { контролювати }\end{array}$} \\
\hline & & 50,35 & 50,32 & 50,26 & 50,24 & 50,32 & & \\
\hline & & 50,48 & 50,46 & 50,35 & 50,35 & 50,23 & & \\
\hline & & 50,25 & 50,38 & 50,24 & 50,26 & 50,39 & & \\
\hline & $t_{c p}$ & 50,340 & 50,353 & 50,275 & 50,285 & 50,313 & 50,31 & \\
\hline & 10 & 51,51 & 51,51 & 51,57 & 51,56 & 51,51 & & \multirow{5}{*}{$\begin{array}{c}\text { Не потрібно } \\
\text { контролювати }\end{array}$} \\
\hline & & 51,54 & 51,61 & 51,53 & 51,53 & 51,49 & & \\
\hline & & 51,52 & 51,51 & 51,47 & 51,51 & 51,51 & & \\
\hline & & 51,59 & 51,49 & 51,52 & 51,52 & 51,52 & & \\
\hline & $t_{c p}$ & 51,540 & 51,530 & 51,523 & 51,530 & 51,508 & 51,53 & \\
\hline & 15 & 51,87 & 52,13 & 51,98 & 52,1 & 51,32 & & \multirow{5}{*}{$\begin{array}{c}\text { Не потрібно } \\
\text { контролювати }\end{array}$} \\
\hline & & 52,21 & 51,85 & 51,65 & 51,67 & 51,81 & & \\
\hline & & 51,69 & 51,76 & 51,54 & 52,93 & 52,3 & & \\
\hline & & 51,92 & 51,52 & 52,01 & 52,87 & 51,21 & & \\
\hline & $t_{c p}$ & 51,923 & 51,815 & 51,795 & 52,393 & 51,660 & 51,92 & \\
\hline & \multirow[t]{4}{*}{20} & 51,65 & 52,12 & 54,01 & 52,09 & 54,07 & & \multirow{5}{*}{$\begin{array}{c}\text { Не потрібно } \\
\text { контролювати }\end{array}$} \\
\hline & & 52,41 & 52,67 & 51,98 & 52,65 & 52,21 & & \\
\hline & & 52,26 & 53,98 & 52,08 & 52,15 & 51,31 & & \\
\hline & & 52,1 & 53,65 & 52,01 & 52,23 & 52,28 & & \\
\hline & $t_{c p}$ & 52,105 & 53,105 & 52,520 & 52,280 & 52,468 & 52,50 & \\
\hline & \multirow[t]{4}{*}{25} & 53,46 & 53,01 & 53,23 & 54,16 & 53,69 & & \multirow{5}{*}{$\begin{array}{c}\text { Не потрібно } \\
\text { контролювати }\end{array}$} \\
\hline & & 54,15 & 54,34 & 53,61 & 53,87 & 54,01 & & \\
\hline & & 52,99 & 53,5 & 54,18 & 53,29 & 53,98 & & \\
\hline & & 53,76 & 53,01 & 53,29 & 52,98 & 53,54 & & \\
\hline & $t_{c p}$ & 53,590 & 53,465 & 53,578 & 53,575 & 53,805 & 53,60 & \\
\hline & \multirow[t]{4}{*}{30} & 55,23 & 54,76 & 54,98 & 54,65 & 55,76 & & \multirow{5}{*}{$\begin{array}{c}\text { Необхідно } \\
\text { зниження } \\
\text { температури }\end{array}$} \\
\hline & & 54,76 & 55,1 & 55,06 & 55,21 & 55,31 & & \\
\hline & & 55,01 & 54,34 & 55,41 & 55,08 & 54,79 & & \\
\hline & & 55,87 & 54,87 & 54,79 & 54,87 & 55,03 & & \\
\hline & $t_{c p}$ & 55,218 & 54,768 & 55,060 & 54,953 & 55,223 & 55,04 & \\
\hline & \multirow[t]{4}{*}{35} & 55,87 & 55,39 & 56,48 & 57,10 & 56,98 & & \multirow{5}{*}{$\begin{array}{c}\text { Необхідно } \\
\text { зниження } \\
\text { температури }\end{array}$} \\
\hline & & 55,43 & 56,93 & 55,98 & 56,43 & 56,73 & & \\
\hline & & 56,21 & 56,34 & 55,76 & 55,98 & 56,83 & & \\
\hline & & 56,87 & 56,01 & 56,21 & 56,49 & 55,63 & & \\
\hline & $t_{c p}$ & 56,095 & 56,168 & 56,108 & 56,500 & 56,543 & 56,28 & \\
\hline
\end{tabular}

Процес температурного режиму сушіння проаналізовано та представлено на основі другого режиму сушіння, який найбільш суттєво відображає процес сушіння у офсетній друкарській машині. Отримана після апроксимації аналітична залежність $\mathrm{T}_{\mathrm{s}}=0,21 \times \mathrm{t}_{\mathrm{s}}+49,52$ для другого режиму, яка характеризує процес взаємозв'язку величини температури сушіння від часу впливу температури сушіння для визначеного режиму сушіння друкарської машини, дозволяе визначити гранич- 


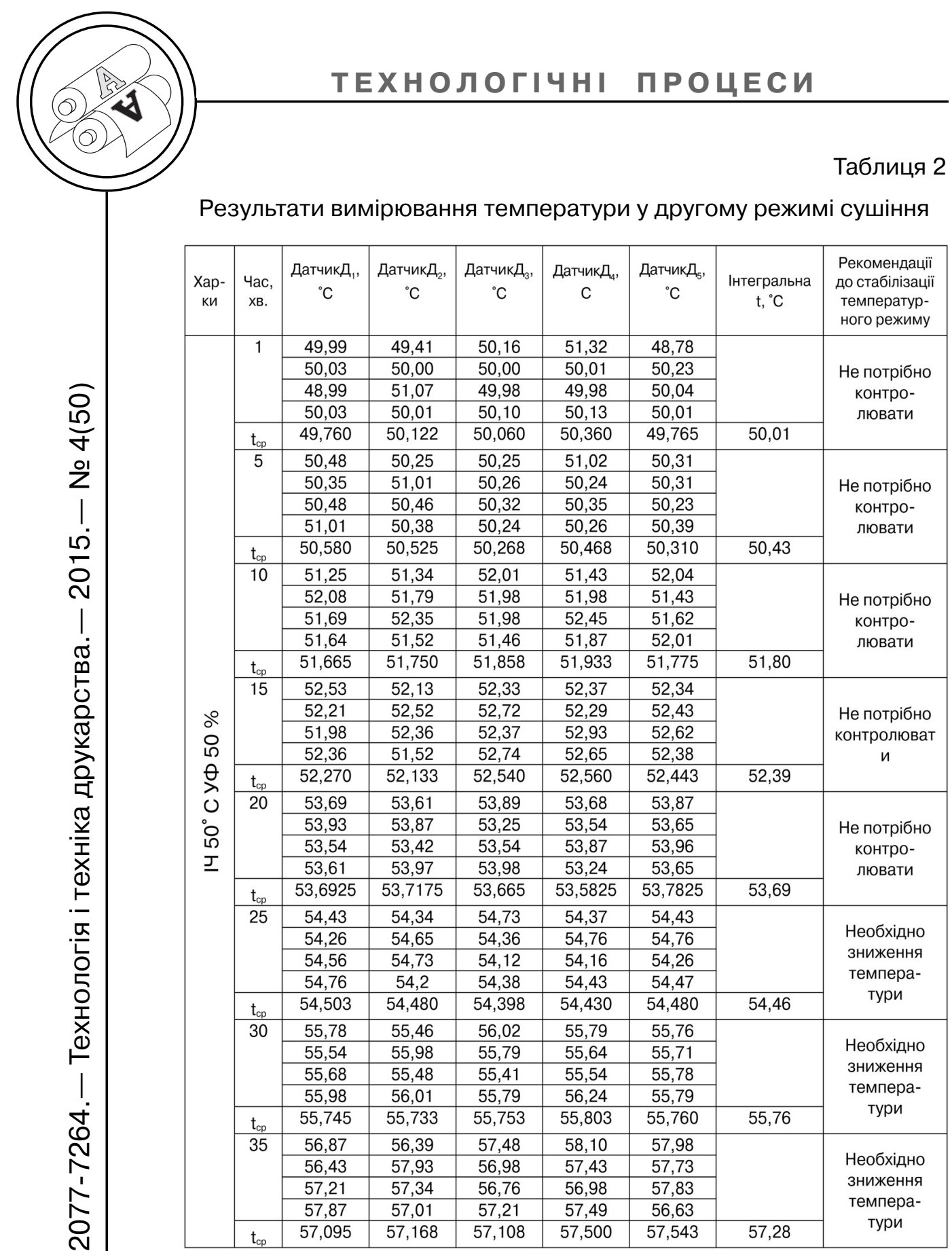

ний час $\mathrm{t}_{\mathrm{s}}=\mathrm{T}_{\mathrm{s}}-49,52 / 0,21$ за максимально допустимою температурою сушильного апарату, до якого зберігається якість друкованої продукції.

Аналогічно побудовані залежності для інших режимів сушіння дозволяють визначити технологію регулювання зниженням температури сушіння або застосування допоміжного контролю температури лише у визначений час $\left(\mathrm{t}_{\mathrm{s}}\right)$ без контролю температури сушіння $\mathrm{y}$ 
Таблиця 3

Результати вимірювання температури у третьому режимом сушіння

\begin{tabular}{|c|c|c|c|c|c|c|c|c|}
\hline $\begin{array}{c}\text { Хар- } \\
\text { ки }\end{array}$ & $\begin{array}{l}4 \mathrm{ac}, \\
\mathrm{xB} .\end{array}$ & $\begin{array}{c}\text { ДатчикД } \\
{ }^{\circ} \mathrm{C}\end{array}$ & $\begin{array}{c}\text { ДатчикД }, \\
{ }^{\circ} \mathrm{C}\end{array}$ & $\begin{array}{c}\text { ДатчикД } \\
{ }^{\circ} \mathrm{C}\end{array}$ & $\begin{array}{c}\text { ДатчикД } \\
{ }^{\circ} \mathrm{C}\end{array}$ & $\begin{array}{c}\text { ДатчикД } \\
{ }^{\circ} \mathrm{C}\end{array}$ & $\begin{array}{c}\text { Інтегральна } \\
\text { t, }{ }^{\circ} \mathrm{C}\end{array}$ & $\begin{array}{c}\text { Рекомендації } \\
\text { до стабілізації } \\
\text { температурного } \\
\text { режиму }\end{array}$ \\
\hline & \multirow[t]{4}{*}{1} & 49,99 & 49,41 & 50,16 & 51,32 & 48,78 & & \multirow{5}{*}{$\begin{array}{l}\text { Не потрібно } \\
\text { контролювати }\end{array}$} \\
\hline & & 50,03 & 50,00 & 50,00 & 50,01 & 50,23 & & \\
\hline & & 48,99 & 51,07 & 49,98 & 49,98 & 50,04 & & \\
\hline & & 50,03 & 50,01 & 50,10 & 50,13 & 50,01 & & \\
\hline & $\mathrm{t}_{\mathrm{cp}}$ & 49,760 & 50,122 & 50,060 & 50,360 & 49,765 & 50,01 & \\
\hline & \multirow[t]{4}{*}{5} & 50,92 & 50,93 & 51,02 & 51,02 & 50,91 & & \multirow{5}{*}{$\begin{array}{l}\text { Не потрібно } \\
\text { контролювати }\end{array}$} \\
\hline & & 50,86 & 51,01 & 50,92 & 50,95 & 50,98 & & \\
\hline & & 50,43 & 50,89 & 50,91 & 50,75 & 50,87 & & \\
\hline & & 51,01 & 50,78 & 50,93 & 51,05 & 50,97 & & \\
\hline & $t_{c p}$ & 50,805 & 50,9025 & 50,945 & 50,9425 & 50,9325 & 50,91 & \\
\hline & \multirow[t]{4}{*}{10} & 52,12 & 52,19 & 52,17 & 52,19 & 52,17 & & \multirow{5}{*}{$\begin{array}{c}\text { Не потрібно } \\
\text { контролювати }\end{array}$} \\
\hline & & 52,1 & 52,14 & 52,16 & 52,08 & 52,16 & & \\
\hline & & 52,13 & 51,98 & 52,09 & 52,17 & 52,17 & & \\
\hline & & 52,09 & 52,16 & 52,05 & 52,09 & 52,16 & & \\
\hline & $t_{c p}$ & 52,11 & 52,117 & 52,117 & 52,132 & 52,165 & 52,13 & \\
\hline & \multirow[t]{4}{*}{15} & 52,69 & 52,61 & 52,7 & 52,37 & 52,61 & & \multirow{5}{*}{$\begin{array}{l}\text { Не потрібно } \\
\text { контролювати }\end{array}$} \\
\hline & & 52,69 & 52,35 & 52,72 & 52,61 & 52,69 & & \\
\hline$a^{0}$ & & 52,51 & 52,74 & 52,67 & 52,93 & 52,62 & & \\
\hline ○ & & 52,63 & 52,45 & 52,51 & 52,65 & 52,38 & & \\
\hline$\theta$ & $t_{c p}$ & 52,630 & 52,538 & 52,650 & 52,640 & 52,575 & 52,61 & \\
\hline 0 & \multirow[t]{4}{*}{20} & 53,99 & 54,01 & 53,89 & 53,98 & 53,98 & & \multirow{5}{*}{$\begin{array}{c}\text { Не потрібно } \\
\text { контролювати }\end{array}$} \\
\hline 웅 & & 53,98 & 54,05 & 54,02 & 53,96 & 53,97 & & \\
\hline$\underline{\Xi}$ & & 53,95 & 53,99 & 53,99 & 54,01 & 53,96 & & \\
\hline & & 53,87 & 53,89 & 53,98 & 54,02 & 53,99 & & \\
\hline & $t_{c p}$ & 53,948 & 53,985 & 53,970 & 53,993 & 53,975 & 53,97 & \\
\hline & \multirow[t]{4}{*}{25} & 56,83 & 56,84 & 56,82 & 56,83 & 56,83 & & \multirow{5}{*}{$\begin{array}{c}\text { Необхідне } \\
\text { зменшення } \\
\text { температури }\end{array}$} \\
\hline & & 56,83 & 56,82 & 56,85 & 56,81 & 56,98 & & \\
\hline & & 56,79 & 56,87 & 56,97 & 56,78 & 56,85 & & \\
\hline & & 56,94 & 56,79 & 56,89 & 56,98 & 56,78 & & \\
\hline & $t_{c p}$ & 56,848 & 56,830 & 56,883 & 56,850 & 56,860 & 56,85 & \\
\hline & \multirow[t]{4}{*}{30} & 57,94 & 57,94 & 57,97 & 57,90 & 57,96 & & \multirow{5}{*}{$\begin{array}{c}\text { Необхідно } \\
\text { зниження } \\
\text { температури }\end{array}$} \\
\hline & & 58,02 & 58,01 & 57,96 & 57,98 & 57,94 & & \\
\hline & & 57,95 & 57,93 & 57,89 & 57,87 & 57,95 & & \\
\hline & & 57,99 & 57,96 & 57,76 & 58,01 & 57,94 & & \\
\hline & $t_{c p}$ & 57,975 & 57,960 & 57,895 & 57,940 & 57,948 & 57,94 & \\
\hline & \multirow[t]{4}{*}{35} & 58,31 & 58,30 & 58,31 & 58,31 & 58,31 & & \multirow{5}{*}{$\begin{array}{c}\text { Необхідно } \\
\text { зниження } \\
\text { температури }\end{array}$} \\
\hline & & 58,29 & 58,25 & 58,34 & 58,32 & 58,35 & & \\
\hline & & 58,30 & 58,27 & 58,32 & 58,29 & 58,29 & & \\
\hline & & 58,40 & 58,30 & 58,29 & 58,31 & 58,28 & & \\
\hline & $t_{c p}$ & 58,325 & 58,280 & 58,315 & 58,308 & 58,308 & 58,31 & \\
\hline
\end{tabular}

проміжку визначеного часу, що забезпечує мінімізацію часу на процес контролю сушіння.

Таким чином, надається можливість для контролю інших параметрів технологічного процесу друку у реальному масштабі часу та визначається напрямок у побудові цифрової системи визначення та регулю- 


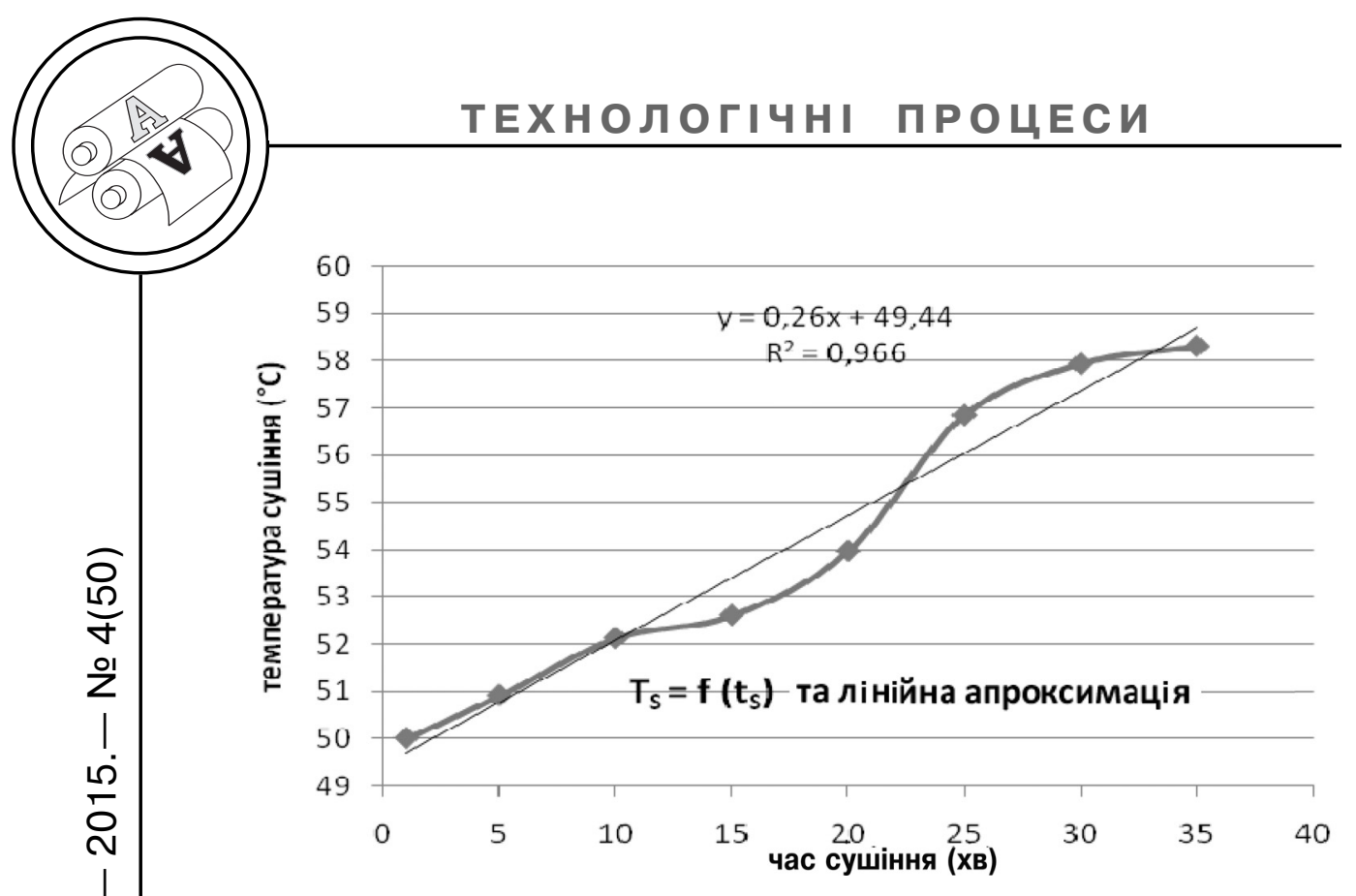

Рис. 4. Графік зміни інтегральної температури $\left(T_{S}\right)$ сушильного апарату від часу впливу $\left(t_{S}\right)$ з третім режимом сушіння

вання температурного режиму сушильного апарату друкарських машин для забезпечення необхідної якості друкованої продукції.

Відповідно до основних функцій стабілізації температурного режиму було розроблено структурну схему системи цифрової температурної стабілізації, що наведена на рис. 1. Система складається з сушильного апарата, датчиків контролю температури сушіння (Д1-Д5), аналогово-цифрових перетворювачів $\left(А Ц \Pi_{1,2,3,4,5}\right)$ для перетворення аналогових сигналів з каналів вимірювання температури у цифровий код, що $є$ передумовою для визначення інтегральної температури сушильного апарату, цифровоаналогового перетворювача $\left(Ц А \Pi_{1}\right)$ і частотного перетворювача (ЧП) для керування температурним режимом сушки та
ЕОМ на основі програмного забезпечення 3 проблемною орієнтацією для визначення i аналізу інтегральної температури сушіння та її стабілізації у реальному масштабі часу.

Для визначення та стабілізації температури сушіння застосовуються алгоритми об'єктивної статистичної обробки результатів цифрового вимірювання, які сприяють підвищенню вірогідності і точності визначення температури сушіння. Застосування цифрових засобів статистичного вимірювання та обробки параметрів температури сушіння на основі проблемноорієнтованого програмного забезпечення (рис. 5), забезпечує виконання процесів визначення та стабілізацію у реальному масштабі часу за рахунок використання швидкодіючих засобів перетворення інформації (АЦП і ЦАП). 
МОДУЛЬ ВИЗНАЧЕННЯ ІНТЕГРАЛЬНОÏ ТЕМПЕРАТУРИ лах»;

НАЧ «СТАТИСТИЧНЕ ВИЗНАЧЕННЯ ТЕМПЕРАТУРИ - ПО 5 кана-

ПРИ NA= 12;

ПРИ $\mathrm{MA}=2{ }^{* \star} \mathrm{NA}$;

ПРИ КР= 70.4;

ПРИ TK= 55;

$$
\text { - кількість розрядів АЦП }
$$

- коефіцієнт перерахунку температури

- температура для визначення регулювання

100 ВЫВ «П О Ч И Н А $\in$ М О виміри температури по 1 - му каналу»;

ВКЛ АЦП12 N1;

ПРИ I=1;

1 ИЗМ КА; - вимір КАЦП на АЦП12 N1

ПРИ T=KA*KP/MA; - визначення температури

ПРИ $\mathrm{T} 1(\mathrm{I})=\mathrm{T}$;

ПРИ $\mathrm{T} 1=\mathrm{T} 1+\mathrm{T} 1(\mathrm{~N})$;

ПРИ I $=\mathrm{I}+1$;

ЕСЛ $(\mathrm{I}>4)$ ПЕР 11 ;

ПЕР 1;

11 ЗАП Т1(I)>TEM1.IZM; - - файл для зовнішнього використання

ПРИ Т1= Т1/4;

ВЫВ «П О Ч И Н А $Є$ М О виміри температури по 2 - му каналу»;

ВКЛ АЦП12 N2;

ПРИ I=1;

2 ИЗМ КА;

- вимір КАЦП на АЦП12 N2

$\Pi P И \mathrm{~T}=\mathrm{KA} A^{\star} \mathrm{KP} / \mathrm{MA}$;

- визначення температури

ПРИ Т2(I)=T;

ПРИ Т2= Т2+ Т2(I);

ПРИ I $=\mathrm{I}+1$;

ЕСЛ (I >4) ПЕР 12;

ПЕР 2;

12 ЗАП Т2(I)>TEM2.IZM; - - файл для зовнішнього використання

ПРИ Т2= Т2/4;

ВЫВ «П О Ч И Н А $\in$ М О виміри температури по 3 - му каналу»;

ВКЛ АЦП12 N3;

ПРИ I=1;

3 ИЗМ КА;

- вимір КАЦП на АЦП12 N3

ПРИ Т $=$ KA*KP/MA; - визначення температури

ПРИ ТЗ $(\mathrm{I})=\mathrm{T}$;

Рис. 5. Програмний модуль на проблемно-орієнтованій мові для температурної стабілізації сушильного апарата. Початок 


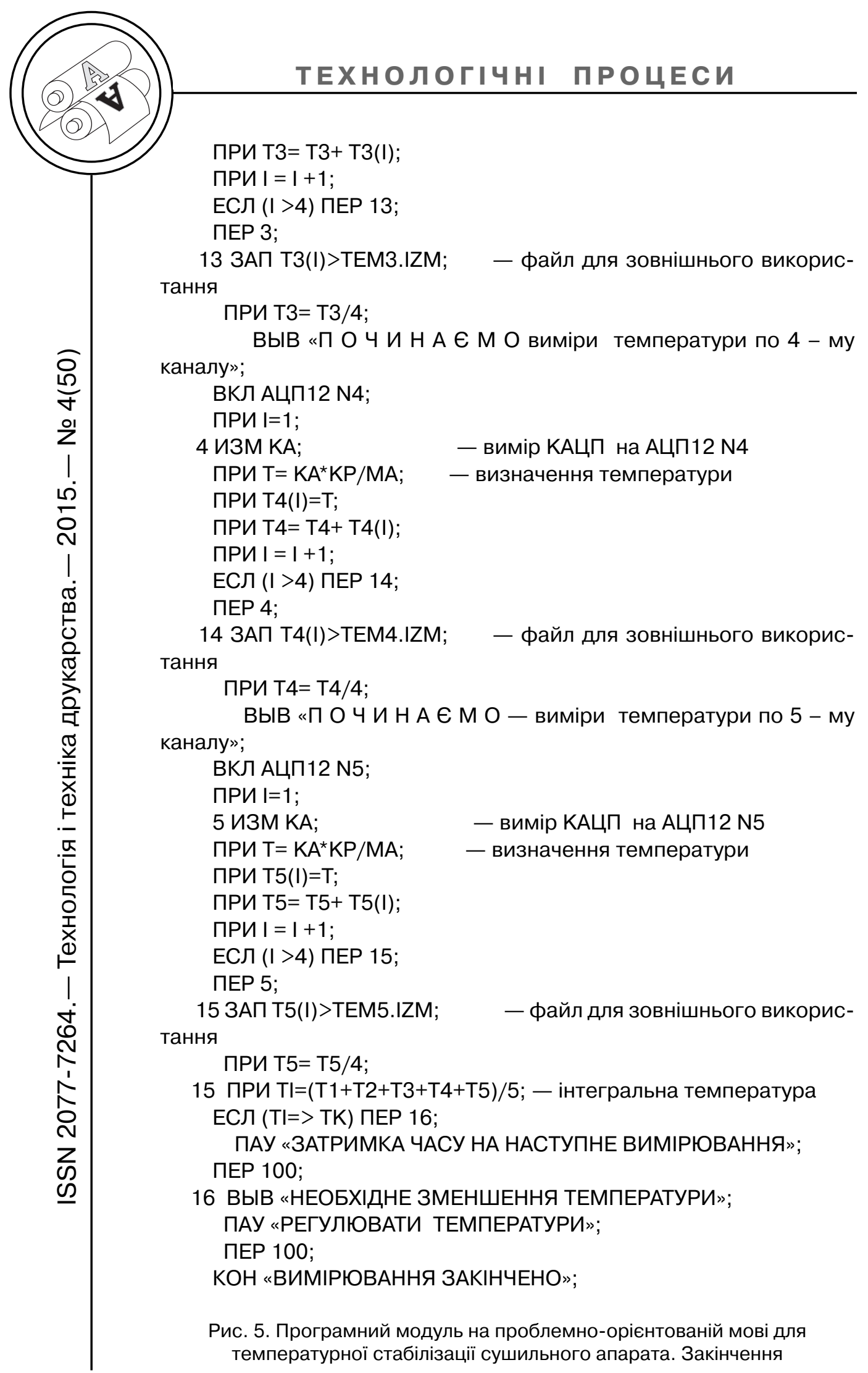




\section{Висновки}

1. Аналіз побудованої залежності режимів сушіння дозволяє визначити технологію регулювання зниженням температури сушіння або застосування допоміжного контролю температури лише у визначений час, без контролю температури сушіння у проміжку визначеного часу, що забезпечує мінімізацію часу процесу контролю сушіння.

2. Побудовано структурну схему системи цифрової стабілізації температурного режиму сушильного апарату, що визначає об'єктивність інтег- ральної оцінки результатів вимірювання та забезпечує регулювання температури сушіння за рахунок адаптивної підтримки оптимальної робочої температури у процесі друку.

3. Застосування цифрових засобів статистичного вимірювання та регулювання температури сушіння на основі проблемно-орієнтованого програмного забезпечення забезпечує точність та достовірність вимірювання у реальному масштабі часу за рахунок використання швидкодіючих засобів перетворення інформації.

\section{Список використаної літератури}

1. Морфлюк В. Ф. Автоматизація процесів контролю технологічних параметрів поліграфічного устаткування / В. Ф. Морфлюк // Друкарство. 2001. - № 1 - С. 34-35.

2. Ефимов М. В. Автоматизированное управление полиграфическим производством / М. В. Ефимов. - М. : Мир книги, 1998. - 416 с.

3. Дроздов В. Н. Автоматизации технологических процессов в полиграфии / В. Н. Дроздов. - М. : Изд-во МГУП, 2006. - 252 с.

4. Барышникова М. Ю. Разработка высокотехнологичного сушильного устройства офсетной печатной машины / М. Ю. Барышникова // Полиграфия : технология, оборудование, материалы : матер. III заоч. науч.практ. конф. с междунар. участием. - Омск, 28-30 мая 2012 г. / Науч. ред. С. Н. Литунов. Отв. ред. И. А. Сысуев. - Омск : Изд-во ОмГТУ, 2012. $140 \mathrm{c}$.

5. Морфлюк В. Ф. Автоматизація процесу контролю температурного режиму сушильного апарата друкарських машин / В. Ф. Морфлюк, Є. В. Сироватка // XIX Міжнародна науково-практична конференція з проблем видавничо-поліграфічної галузі : тези доповідей. - К., 2014. - С. 64-66.

\section{References}

1. Morfliuk V. F. Avtomatyzatsiia protsesiv kontroliu tekhnolohichnykh parametriv polihrafichnoho ustatkuvannia / V. F. Morfliuk // Drukarstvo. - 2001. № $1-\mathrm{S}$. 34-35.

2. Efimov M. V. Avtomatizirovannoe upravlenie poligraficheskim proizvodstvom / M. V. Efimov. - M. : Mir knigi, 1998. - 416 s.

3. Drozdov V. N. Avtomatizacii tehnologicheskih processov v poligrafii / V. N. Drozdov. - M. : Izd-vo MGUP, 2006. - 252 s.

4. Baryshnikova M. Ju. Razrabotka vysokotehnologichnogo sushil'nogo ustrojstva ofsetnoj pechatnoj mashiny / M. Ju. Baryshnikova // Poligrafija : tehnologija, oborudovanie, materialy : mater. III zaoch. nauch.-prakt. konf. s mezhdunar. uchastiem. - Omsk, 28-30 maja 2012 g. / Nauch. red. S. N. Litunov. Otv. red. I. A. Sysuev. - Omsk : Izd-vo OmGTU, 2012. - 140 s. 
5. Morfliuk V. F. Avtomatyzatsiia protsesu kontroliu temperaturnoho rezhymu sushylnoho aparata drukarskykh mashyn / V. F. Morfliuk, le. V. Syrovatka // XIX Mizhnarodna naukovo-praktychna konferentsiia z problem vydavnycho-polihrafichnoi haluzi : tezy dopovidei. - K., 2014. - S. 64-66.

\title{
В статье представлена организация цифровых программно- аппаратных средств определения и стабилизации температурного режима сушильного аппарата печатных ○. машин, которые обеспечивают объективность интегральной оценки измерений в реальном масштабе времени на основе проблемной ориентации.
}

\begin{abstract}
Ключевые слова: температура сушильного аппарата печатных машин; программно-аппаратные средства с проблемной ориентацией; интегральное статистическое измерение; стабилизация температурного режима.
\end{abstract}

The article presents the organization of digital software and hardware definitions and stabilizing temperature drying machine of printing machines, which provides an objective assessment of the integrated measurements in real time, based on problem orientation.

Keywords: temperature of drying vehicle of printing presses; software and hardware definitions a problem orientation; integral statistical measuring; stabilizing of temperature condition.

Рецензент - О. М. Величко, д.т.н., професор, НТУУ «КП|» 